\title{
The fortification of Alicante designed by the engineer Ambrosio Borçano
}

\author{
M. I. Pérez Millán, A. B. González Avilés \& V. Echarri Iribarren \\ Department of Building Construction, University of Alicante, Spain
}

\begin{abstract}
Since the fortification of Alicante was implemented in 1535, the city had not developed any defensive features which could counteract sea attacks. The extramural growth of the city into the suburb of San Francisco seriously hindered its defence, which was proven with the French bombardment of 1691 after more than 150 years of inactivity. By 1677 Grand Master Borçano Ambrosio drew up a plan of a new defence for Alicante that would eventually not be carried out but would be the foundation of the bastion of San Carlos, the only defensive bastion carried out after the bombardment to protect against an attack from the sea.

Keywords: Alicante, military engineers, Ambrosio Borçano, fortification, San Carlos bastion.
\end{abstract}

\section{Introduction to the history}

Following the death of King Felipe IV works on fortifications in the Spanish Levante went through a period of inactivity. The Regency of Mariana of Austria started out through bankruptcy in 1666 which led to the continued inactivity of defensive works. Fortified strongholds in Spain were in a pitiful state, bar a few exceptions. Alicante did not differ much from other Spanish strongholds; a large majority of fortified strongholds demonstrated incorrect or old walls, a lack of bastions and too many modernisation works to be completed [1]. In cities like Badajoz, or fortifications in the Principality of Catalonia which were carried out by Ambrosio Borçano [2], limited their work to maintaining only the existing fortification and carrying out some minor repairs. Similarly, the description of the works in Pamplona by Master Amador Lazcano in 1669 reflected the limited progress in this decade [3, pp. 259-265]. 
The situation in Alicante was troubling. The news that there was a presence of British ships in Mediterranean waters was constant. In 1661 the threat of an attack by British troops overpowered the city again when troops landed in Alicante port. The British measured the walls and took notes of obstacles and fortifications in the city. It was a very tense situation, even more so because the reasons they gave for docking contradicted. On the one hand, the English made claim that they had stopped on the way to Algiers. Moreover, they claimed they were waiting for a ship that had stopped in Portugal. Soon enough alarms sounded with artillery and cavalry mobilising in the stronghold of Alicante for several nights. Finally, nothing happened and the British left the bay without any altercation. However, there is no denying that the continued nervousness that the city was subjected to caused concern; the frontiers were too open and Spanish weapons were defeated again and again by Portuguese troops.

In May 1667 Louis XIV placed about 70,000 troops on the border of Flanders, leading to a new war with France, the War of Devolution. A war that hurried about a solution to the war in Portugal.

The reign of Carlos II in the last quarter of the seventeenth century, characterised by the wars that followed, led to a dramatic chapter in the story of Alicante and Santa Barbara Castle. In 1681, France entered into war with the Netherlands, taking Strasbourg and Kortrijk strongholds. To restore peace, in exchange he demanded the equivalent in Catalonia, strongholds such as Puigcerdá, Gerona and others, in Navarre he demanded the strongholds of Hondarribia and Pamplona. Following this, Spain once again declared war on France shortly after $23^{\text {rd }}$ October 1683.

Given this hostile period, the latter part of the seventeenth century was characterised as a series of efforts were carried out to fortifications on the Peninsula so that they were able to withstand prolonged sieges.

\section{Defensive state of the Alicante fortification}

In the seventeenth century, Alicante's defence was in virtually the same state as it was during the sixteenth century. On the one hand, the "fortification transition" executed during the reign of Carlos $\mathrm{V}$ had left obsolete circular towers defending the city from new advances in artillery. On the other hand, the poor condition of the walls and the expansion of the suburbs outside the walls, left clear evidence of inattention to the possible invasion of an enemy army [4]. (During the reign of Felipe II in the second half of the sixteenth century, well-respected engineers conducted various projects for the fortification and defence of the city of Alicante. Neither could be carried out through lack of resources and for being too ambitious. The defence of the castle of Alicante was left as low priority, which itself underwent major changes in its defensive structure, providing it with a modern structure, under plans by engineers such as Antonelli, Vespasian Gonzaga and Fratín.)

Consultation with the War Council on $27^{\text {th }}$ May 1667, where necessary discussions on the precautions to take in order to defend Spain took place, clearly described the state of fortifications in the second half of the seventeenth 
century. Through the declaration of war by Louis XIV, the Marquis of Montara wrote that Spanish fortifications were ruined with no people, no ammunition and no artillery and they very quickly needed improving [5].

In Alicante, enemy troops could only attack by sea. Perhaps this is why the only work done in recent years was the provisional breastwork at the end of the pier, which was weak and ineffective. All other works were limited only to the supply of ammunition. It would have seemed more logical that the city might have ordered more work on the waterfront. This follows on from the work by Francisco Terrenq of $16^{\text {th }}$ October 1667: "List of artillery needed at the castle and the square of the city of Alicante for it's proper defence", which shows that most were concentrated in the vicinity of the castle close to the sea [6].

On $25^{\text {th }}$ March 1668, the viceroy again requested that munitions and supplies were needed in the stronghold and castle of Alicante [7]. The vice-chancellor of Aragon responded favourably to the request and on $20^{\text {th }}$ July 1668 sent correspondence to Peniscola and Alicante that the munitions request must be carried out [8].

However, the problem in Alicante went beyond the need for a large number of artillery, ammunition and soldiers. For some time the city had come to occupy a much more spread out space than in its walls and so the need to expand the fortifications of San Francisco was considered (Figure 1).

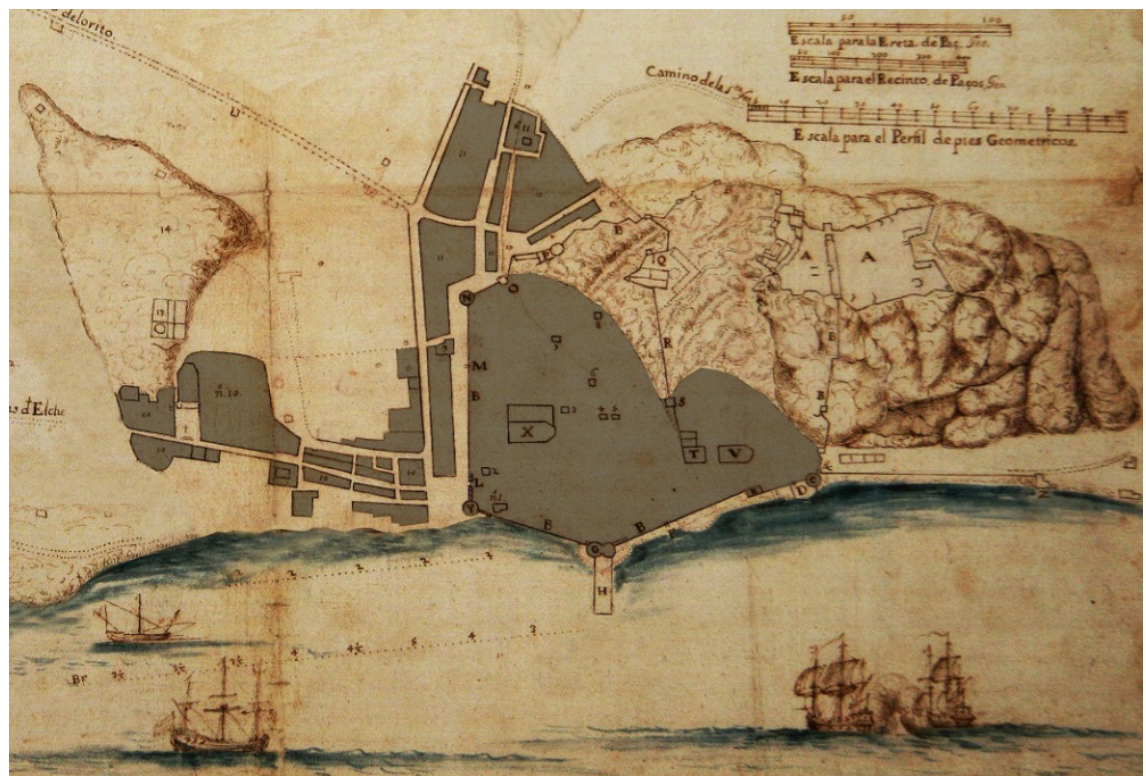

Figure 1: Plan drawn up by the original authors Castellón and Valero in 1688. The shaded area is the walled enclosure of Carlos V and the suburbs of San Francisco and San Antón. Plan from SGE. CH. $\mathrm{N}^{\mathrm{o}} 287$. 
The situation represented a real danger under siege. However, the problem was only solved if the suburbs were surrounded by a new enclosure and prevented armed enemies from taking land. This was a common drawback in the strongholds of the time. The growth of the population did not allow inhabitants to stay inside the enclosure due to a lack of space. Despite the king's instructions that prohibited buildings near the walls, local governments ignored this due to the revenue they brought in [9].

After many decades of neglect the Alicante stronghold was considered second in defending the mainland but the constant threat of the army of Louis XIV led to the drafting of a defence project that housed the suburbs (the extramural buildings) of the city.

\section{Ambrosio Borçano's work [10]}

Ambrosio Borçano, from the city of Milan, served for thirty-five years as an engineer in the state of Milan, Extremadura and Gibraltar. In Extremadura he served as a military engineer between 1660 and 1672. His activity in the Royal Army of Extremadura meant that the plans for Estremoz, Valencia de Alcantara, Alcantara, Moral and Setúbal [11] were preserved. In 1669 he was appointed military engineer of the Army of Catalonia and only two years later he was appointed engineer for the project in Panama. In 1672 he took control as the third Count of Montijo in Gibraltar. In 1673 he moved to the Catalonian army as lieutenant general of artillery and during the impending conflict with France was appointed general master and engineer of the army with the rank of field marshal in 1677. For twelve years, he was recognised throughout the Principality and carried out surveys of towns and villages on behalf of the state, seeing none of them "in divine perfection". He died in 1698 at the age of 66.

Although there has not been any documentation about the fortification of Alicante project, we know its design thanks to information collected in a design of 1688 through military engineers Joseph Castellón and Pedro Joan Valero, which is preserved in the Military Geographical Service [12]. A dotted line indicates the plan of the project by Ambrosio Borçano, who was appointed lieutenant general of artillery and army barracks Master General of Catalonia in 1673 [13] (Figure 2).

Borçano Ambrosio's experience in fortification was vast. His General Address throughout Catalonia, Roussillon and Cerdanya created geographical capacity across Catalonia to maintain an army in continual campaign, pointing out the best places to develop military operations [14] (see more in [15]). He informed over twenty strongholds and many other towns in the Principality of Catalonia. We do not know the exact date on which the Alicante project was drafted, although it was probably close to 1677 , when he was commissioned to carry out surveys of Peñiscola and all other strongholds in the kingdom of Valencia. This inspection was completed around the $14^{\text {th }}$ January and was sent on $6^{\text {th }}$ February 1678 [16]. We know from his stay on the Valencian coast through a statement made by the Count Viceroy of Aguilar and Frigiliana as the Viceroy requested the presence of an army engineer in Catalonia to report on 


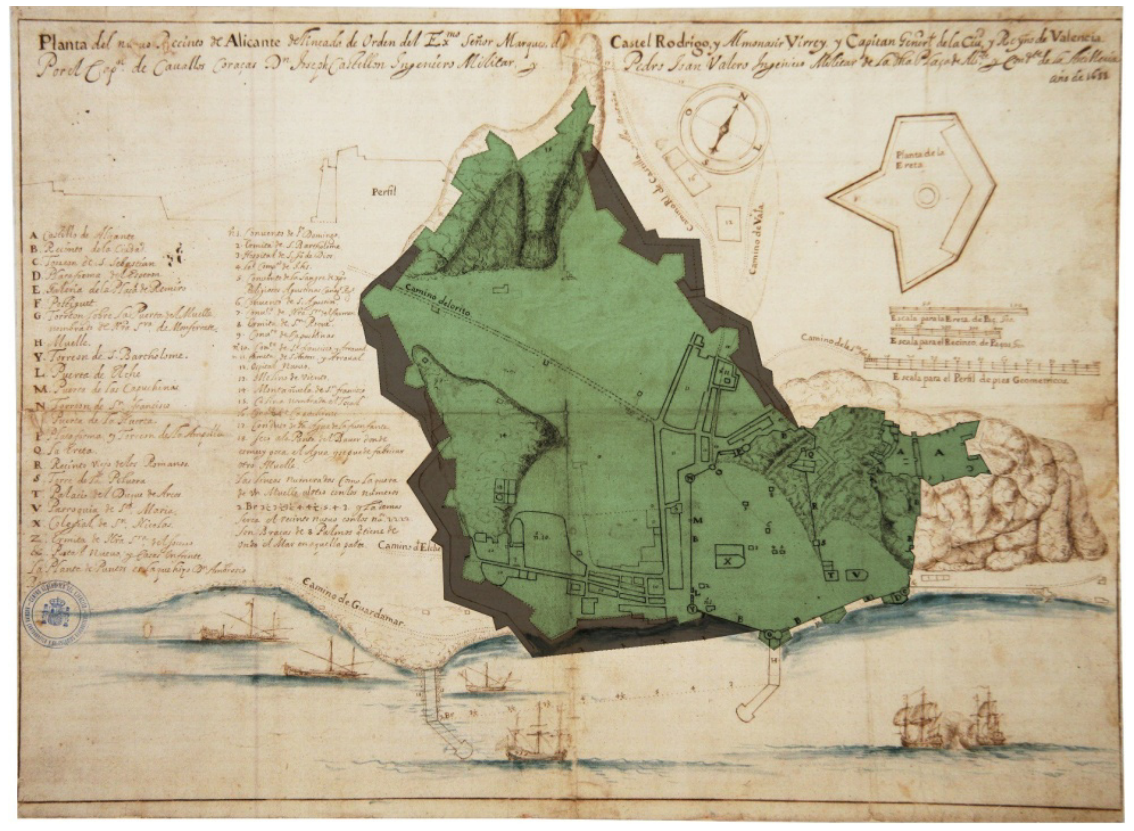

Figure 2: $\quad$ Plan drawn up by original authors of Castellón and Valero in 1688. The shaded area is the enclosure designed by Ambrosio Borçano. Plan from SGE. CH. N 287.

the needs of Peñiscola. (Rodrigo Manuel Fernández Manrique de Lara Ramírez de Arellano Mendoza y Albarado (1638-1717), Count of Aguilar and 2nd Count of Frigiliana.) The engineer proposed was initially Rynaldi, but he was busy working on the defences in Gerona and Cartagena [17]. Finally Borçano Ambrosio was appointed to the position and project managed the necessary works, garrison and ammunition improvements [18]. Similarly he was to travel to Alicante to understand the needs of the stronghold and draw up plans for a new enclosure.

The proposal included a bulwark which was located at the entrance of the ravine at San Blas. This was the stronghold of a larger project that would give rise in later years to the bastion of San Carlos (figure 3). His mission was clear: cover the bay and any landing attempt on the beach of Bavel.

From the bastion of San Carlos to Monte Tosal, five more bastions were proposed by Borçano all with retaining walls. By including Monte Tosal it prevented the enemy from using it as an obstacle to allow an attack on the stronghold and the castle. Tosal was fortified by uneven walls and breastworks, highlighting its importance.

From this point the fortification was heading towards the junction of the wall that descends from the castle up to the walls of the Old Village (Villa Vieja), above the bastion of Ampolla. The northern part was fortified with three bastions defending an advance on the inside. 


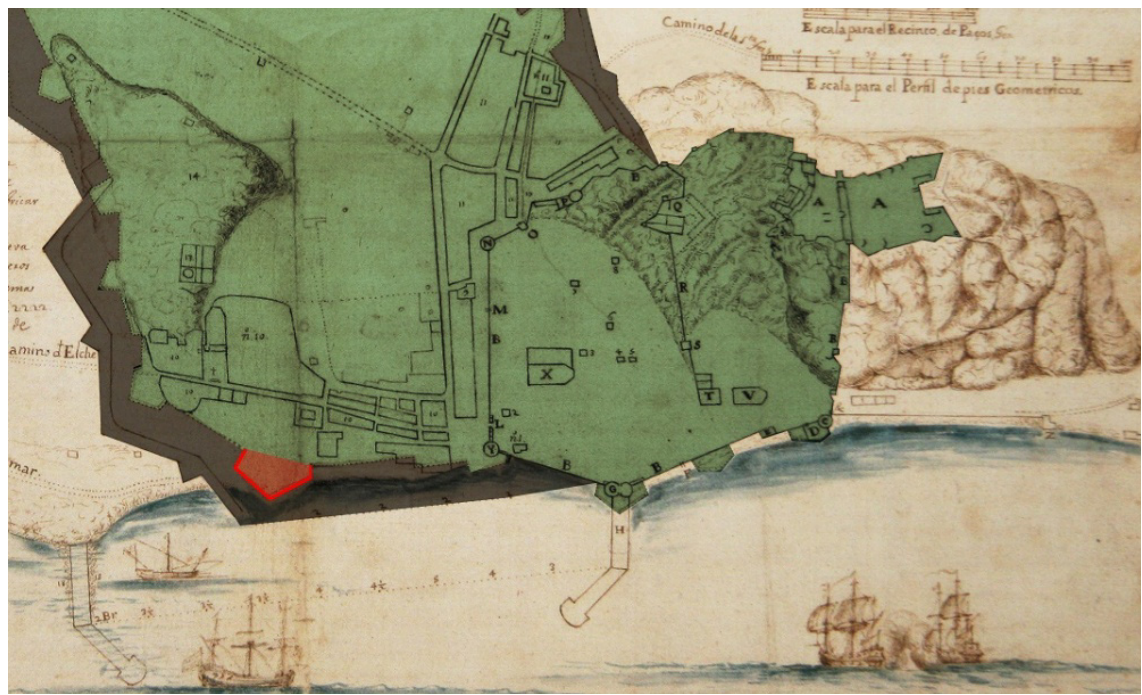

Figure 3: $\quad$ Plan drawn up by original authors of Castellón and Valero in 1688. Shaded red is the bastion of San Carlos. Plan from SGE. CH. $\mathrm{N}^{\mathrm{o}} 287$.

Borçano's other proposal was to design a plan for a fort at Ereta where the store of gunpowder would be located. This comprised of a small plain on one side of Benacantil, halfway between the city and the castle, from there the city and part of the coast would be a dominant strategic point.

The layout included the inside wall of the suburbs of San Francisco and San Anton, San Francisco mountain and Monte Tosal and a fivefold increase in surface enclosure of the fortification the city had at this time.

For the project Borçano had to adapt and change the terrain and fit the shape of its bastions and barrages around the existing rugged terrain to the west of Alicante. He went against a plan for symbolic geometry, which would certainly be give greater defensive capabilities from the outside and instead chose to follow the plans of the famous Prestre Sebastien Le Vauban, a prominent figure in the art of fortification defensive systems. He streamlined both strongholds with a flat environment and for those who were located in hilly reliefs. Throughout the enclosure Borçano sought an adequate proportion between the face of the bastions and breastwork on the front, with an adjusted flanking distance so that firepower of artillery and rifle shots could be allowed.

An enclosure of this size had serious drawbacks. The amount of resource involved in the works added the need for a huge garrison to defend the stronghold. Both defensive options were unsustainable given the state of the overstretched finances. Also if the enemy could penetrate the part of Tosal and mount a strong advance there, the stronghold would be captured. Following that the castle stronghold would be next. If they decided to make strong progress at the top of the mountain instead of around it, the enemy would be forced to 
capture it first, and then mount an attack on the fortified city. However, the defence could move quickly so that the attackers could not exploit the existing fortifications. Both situations were reflected in subsequent proposed fortifications in Alicante throughout the eighteenth century. The option to fortify Tosal would take place in the early nineteenth century with the construction of the castle of San Fernando.

It is of particular interest that the design which Borçano made did not include any outside help: revellines, counterguards, forts, amongst other things. Arguably this was contradictory because the outer fortifications were always included in other ambitious projects like this. Experts agreed, in recent decades, that it was essential for a well-withstanding siege to have revellines on all fronts and the strongest counterguards and horsemen placed at strategic points to fight the attackers. The design Borçano made probably contemplated that of Girona [19] or Alcantara [20], although the design of Castellón y Valero did not include this.

If we look at cities like Cartagena or Pamplona, to give two examples of cities whose bastions match a project of this magnitude, this idea is reinforced. In 1678 , the year to which we date Borçano's design of Alicante, Rynaldi proposed to fortify Cartagena with a platform and fort in Trincabotijas [17]. In 1683, the military engineer Octavian Menni outlined a project for the fortifications of Pamplona in which some revellines included three strong outer areas [3, pp. 277-84].

\section{Conclusion}

Borçano's project was technically sound, demonstrating his craft and experience.

The drawbacks described in Borçano's project, mainly the cost of the important work and the need for a disproportionate garrison to the real possibilities available in Alicante, made subsequent projects exclude the idea of integrating Monte Tosal. Unfortunately, by not having the record attached to this project, we do not know if outer fortification works were dismissed.

The project never was built and the city defence systems relied upon Santa Barbara's castle for protection.

In 1688, after the ambitious Borçano's project, another similar project was developed by Joseph Castellón and Pedro Joan Valero whose interest may be contrasted by their influence in the first third of the eighteenth century arose. Undoubtedly the design was very reminiscent to that of Ambrosio Borçano keeping in with the design of the bastion of San Carlos in the same place where Borçano had planned it to be (figure 4).

The proposal brought about the defensive fortress located at the entrance of ravine of San Blas. It was the stronghold of a larger project and became the only defensive element executed years after to repel a sea attack.

During the last two decades of the seventeenth century, naval military operations by the French navy in the Mediterranean would result in the bombardment of Genoa (1684), Barcelona (1691), Alicante (1691) and Malaga (1693). In 1691 the French fleet under the command of General d'Estrees, after 


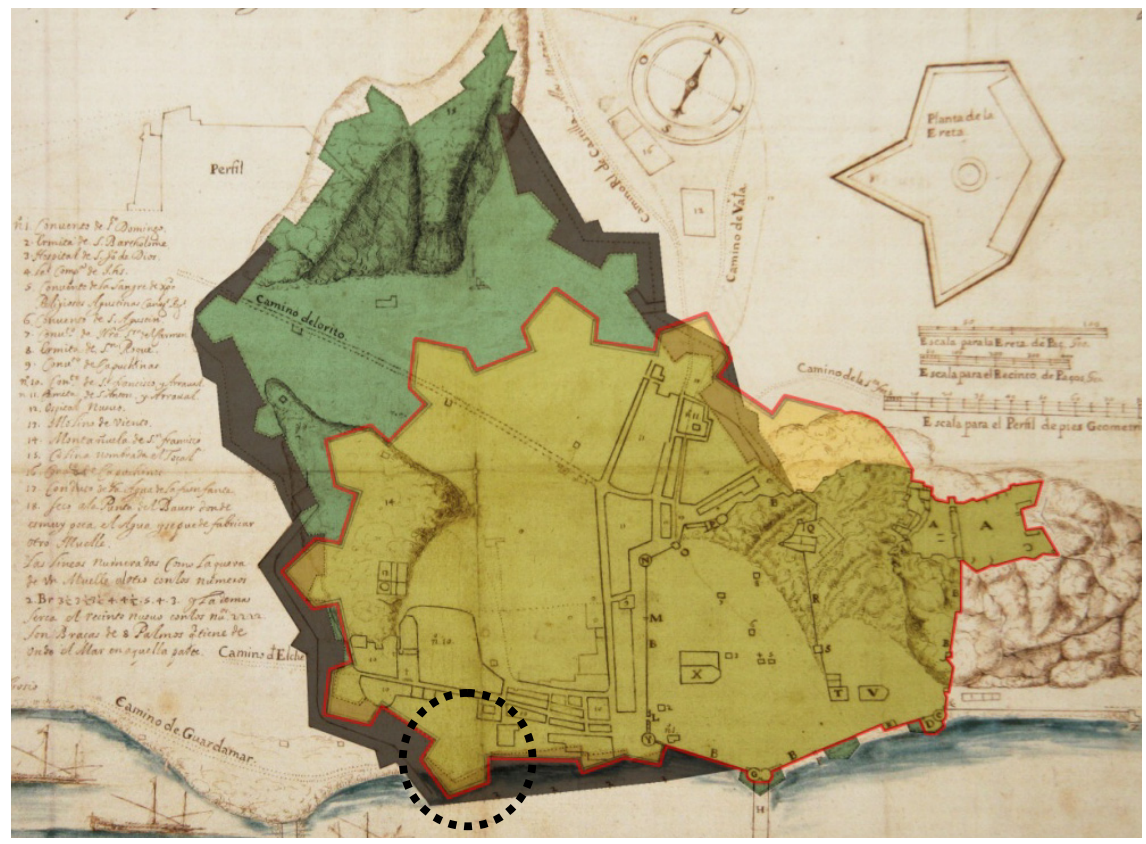

Figure 4: $\quad$ Plan drawn up by original authors Castellón and Valero in 1688. Overlay location of the bastion of San Carlos (indicated by a dotted line). The proposal by Borçano is in green, red and the yellow shaded area is the proposal by Castellón and Valero. Plan from SGE. CH. N 287.

bombing Barcelona, relentlessly attacked the city of Alicante leaving it virtually destroyed and demonstrating the non-existent effectiveness of the defenses executed to date. Probably the defensive stronghold proposed by Borçano for the harbour could have offered much more resistance. (The construction of the fortress began in 1691 following the bombardment.)

\section{References}

[1] Espino López, A., El frente catalán en la Guerra de los Nueve Años, 1689-1697, Tesis doctoral, Universitat Autónoma de Barcelona, 1994, p. 262.

[2] Garcia Blanco, J., Las fortificaciones entre 1668 y 1675. La muralla de Badajoz. De la cerca medieval a la cerca abaluartada (1679-1700), 2010,

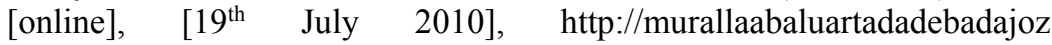
.blogspot.com/2010/07/2.html

[3] Echarri Iribarren, V., Las Murallas y la Ciudadela de Pamplona, Gobierno de Navarra, Departamento de Cultura y Turismo, Institución Príncipe de Viana. Pamplona, 2000, 
[4] Echarri Iribarren, V., Pérez Millán, M. I., \& González Avilés, Á. B., "La competitividad de Vespasiano Gonzaga y el Fratín sobre la modernización de las estructuras del castillo de Alicante en la segunda mitad del siglo XVI", in Concursos de arquitectura: 14 Congreso Internacional Expresión Gráfica Arquitectónica. Oporto (Portugal), Portugal mayo de 2012. ISBN 978-84-8448-708-1.

[5] AGS. Negociado de Guerra. Leg. 2.134. IHCM. Colec. Aparici. Tomo XIII. 1-5-13.

[6] ACA. Consejo de Aragón. Leg. 561. Fol. 45/12. Relación de Francisco Terrenq a 16 de octubre de 1667.

[7] ACA. Consejo de Aragón. Leg. 561. Fol. 45/21.

[8] ACA. Consejo de Aragón. Leg. 561. Fol. 45/26.

[9] Maltés, J.B.; López, L., Ilice ilustrada Historia de las antigüedades, grandezas y prerrogativas de la muy noble y siempre leal Ciudad de Alicante, Edición facsímil del manuscrito conservado en el Archivo Municipal de Alicante de mediados del siglo XVIII, de fecha 1752, Alicante, 1907, Nota 138.

[10] IHCM. Copia Aparici. Ingenieros. Burgueño, J. (ed.), El mapa com a llenguatge geográfic. Recull de textos histórics (ss. XVII-XX), Societat catalana de geografía. Barcelona. 2008, pp. 19-20.

[11] Testón Núñez, I.; Sánchez Rubio, R.; Sánchez Rubio, C., La memoria ausente. Cartografía de España y Portugal en el archivo Militar de Estocolmo. Siglos XVII y XVII, Ed. 4 Gatos, Badajoz, 2006, p. 6 del Estudio Introductorio, [online], [23 de septiembre de 2010], http://www.4gatos.es /MemoriaAusente/indexint.htm

[12] SGE. CH. 287.

[13] Cámara Muñoz, A. (Coord.), Los ingenieros militares de la monarquía hispánica de los siglos XVII y XVIII, Ministerio de Defensa, Asociación española de amigos de los castillos y Centro de Estudios de Europa Hispánica, 2005, p. 89.

[14] Espino López, A., El frente catalán en la Guerra de los Nueve Años, 1689-1697, Tesis doctoral, Universitat Autónoma de Barcelona, 1994, pp. $240-267$.

[15] Espino López, A., "Las fortificaciones catalanas a finales del siglo XVII: la obra de Ambrosio Borçano", in Arquitectura e Iconografía artística militar en España y América (siglos XV-XVII1), Sevilla, 1999, pp. 93-113.

[16] AGS. Guerra Antigua. Leg. 2411. Relationship between Ambrosio Borçano and the Duke of Ciudad Real's stronghold in Peñiscola and its artillery in 1678 .

[17] Guimaraens Igual, G., El último hálito de la fortificación abaluartada: el fuerte de San Julián de Cartagena, Tesis doctoral, Director: Juan Francisco Noguera Giménez, Departamento de Composición Arquitectónica, E.T.S. Arquitectura de la Universidad Politécnica de Valencia, 2008, p. 1058. 
[18] Espino López, A., Guerra, fisco y fueros. La defensa de la Corona de Aragón en tiempos de Carlos II, 1665-1700, Universitat de València, Valencia, 2007, p. 135.

[19] Girona: Planta de la ciudad y fortificaciones. Borsano, Ambrosio. Material cartográfico manuscrito. [1673-1687?] [online], http://bibliotecadigitalhispanica.bne.es/R/8R4KGTHCVVSB9YA5DD31 YV275DHC1KNLYHV227F855XSJTCV2E-03022? func=results-jumpfull\&set_entry $=000008 \&$ set number $=000103 \&$ base $=$ GEN01

[20] Utländska stads- och fästningsplaner. Spanien. Valencia de Alcantara. H1688. Ambrosio Borsano. [Online], 2012. www.4gatos.es 